\title{
«ВАЛЮТА ДЛЯ П’ЯТИРІЧКИ»: ШИПЧАНДЛЕРСТВО У СИСТЕМІ ВСЕСОЮЗНОГО ОБ'ЄДНАННЯ «ТОРГЗІН» ПЕРШОЇ ПОЛОВИНИ 1930-х рp.
}

Анотація: у статті досліджується організація торгзінівської портової торгівлі першої половини 1930-х рр. Доведено, що створення портових торгзінів стало частиною загального процесу мобілізації та централізації валютних коштів на потреби індустріалізації. «Торгзін» був покликаний перетворити портову торгівлю у канал стабільних надходжень валюти до державного бюджету. Встановлено, що діяльність радянських шипчандлерств не була належним чином організована. Однак, директори портових «Торгзінів» намагалися будь-якою иіною виконати доведений їм валютний план і використовували для цього усі можливі та неможливі способи. З'ясовано, що хоча валютні доходи від портового господарства були незначними, шипчандлерство, краще ніж інші операщії у системі «Торгзін», розкрило його суть.

Ключові слова: СРСР, УСРР, «Торгзін», шипчандлерство, портова торгівля, валюта

Встановлення більшовиками радянської влади вимагало практичної реалізації їх популістської програми. Закладена в її основу модернізація країни, особливо технічної бази, потребувала величезних затрат на імпорт засобів виробництва. Скромні можливості радянської економіки не могли задовольнити амбітні бажання кремлівських можновладців. Однак вони намагалися використати усі засоби для реалізації задуманого.

Одним із таких засобів став «Торгзін» - Спеціальна контора для постачання іноземних суден у радянських портах та обслуговування іноземців на території СРСР. Вона була створена 18 липня 1930 р. постановою Народного комісаріату зовнішньої торгівлі СРСР 3 метою спецобслуговування іноземних туристів ${ }^{1}$.

Проблема дослідження організації та діяльності системи «Торгзін» відносно нова в історичному науковому дискурсі. Наукова розробка теми «Торгзіну» стала можливою після розпаду СРСР і розсекречення архівних фондів. Першою на пострадянському просторі наукову проблему окреслила російський історик О. Осокіна ${ }^{2}$, якій ще у другій половині

\footnotetext{
* Сокирська Владилена Володимирівна - доктор історичних наук, професор кафедри всесвітньої історії, міжнародних відносин та методики навчання історичних дисциплін Сумського державного педагогічного університету імені А.С. Макаренка (м. Суми) ORCID: https://orcid.org/0000-0002-9983-3234; e-mail: vlada.sokirskaya@ukr.net

${ }^{1}$ Осокина Е.А. За зеркальной дверью торгсина // Отечественная история. 1995. № 2. С. 86.

${ }^{2}$ Осокина Е.А. Шлите доллары на торгсин // Родина. 1997. № 2. С. 70-73; Осокина Е. За фасадом «сталинского изобилия»: распределение и рынок в снабжении населения в годы индустриализации (1927-1941). Москва, 1999. 271 с.; Осокина Е.А. Доллары для индустриализации: валютные операции в 1930-е годы // Родина. 2004. № 3. С. 76-81; Осокина Е.А. Советская жизнь: обыденность испытания: (На примере Торгсина и ОГПУ) // Отечественная история. 2004. № 2. С. 113-124; Осокина Е.А. Золотая лихорадка по-советски // Родина. 2007. № 9. С. 111-117; Осокина Е.А. Золото для индустриализации: «Торгсин». Москва: РОССПЭН, 2009. 592 с.; Осокина Е.
} 
1990-х рр. вдалося натрапити у російських архівах на документи, що розкривають масштаби діяльності «Торгзіну» в СРСР. Провідний український історик, дослідник Голодомору 1932-1933 pр., професор В.I. Марочко першим в Україні розкрив питання поширення діяльності торгзінівської системи в УСРР і довів, що ця проблема має безпосереднє відношення до голодного лихоліття тих років ${ }^{3}$. Дослідження окресленої провідними істориками проблеми продовжили в Україні В. Даниленко ${ }^{4}$ М. Горох ${ }^{5}$, О. Мельничук ${ }^{6}$, Я. Міщук ${ }^{7}$ В. Танасюк ${ }^{8}$, у Російській Федерації - О. Орєшкін ${ }^{9}$, Ф. Семенова ${ }^{10}$.

Автор цієї статті ставить за мету показати особливості організації діяльності торгзінівської торгівлі в українських портах, оскільки у працях істориків означена проблема не знайшла належного та повного висвітлення.

Створення портових торгзінів стало частиною загального процесу мобілізації та централізації валютних коштів на потреби індустріалізації. «Торгзін» був покликаний перетворити портову торгівлю у канал стабільних надходжень валюти до державного бюджету. 3 цією метою при правлінні «Торгзіну» у Москві наприкінці 1930 р. було організовано Портовий директорат ${ }^{11}$.

«Советские дома терпимости»: рассказы о портовых торгсинах 1930-х гг. // Вестник РУДН. Серия: «История России». 2007. №2. С. 50-64; Осокина Е.А. Торгсин в советской экономической системе 1930-х годов // Труды Института российской истории. Вып. 11. Москва, 2013. С. 206-226.

${ }^{3}$ Марочко В. Діяльність торгсинівської системи міста Києва // Проблеми історії України: факти, судження, пошуки. 2008. Вип. 18. С. 163-174; Марочко В.I. Торгсини Києва в роки Голодомору // Україна ХХ ст.: культура, ідеологія, політика. 2009. Вип. 15. Ч. 2. С. 63-77; Марочко B.I. «Торгсин»: золота ціна життя українських селян у роки голоду (1932-1933) // Український історичний журнал. 2003. № 3. С. 90-103; Марочко В.I. Обмін побутового золота на хліб в Україні періоду Голодомору 1932-1933 років // Український історик. 2008. № 3-4. С. 194-209; Марочко B.I. Торгсини Києва: хліб за золото. Національна книга пам'яті жертв голодомору 19321933 років в Україні: місто Київ. Київ: Фенікс, 2008. С. 58-65; Марочко В.І. «Золотий дощ» 1932-1933 рр. // Урядовий кур'єр. 2009. 11 лютого. № 24. С. 13.

${ }^{4}$ Даниленко В.М. Розкрадання продуктів та промтоварів госпорганами та системою Торгсину. Національна книга пам'яті жертв голодомору 1932-1933 років в Україні: місто Київ. Київ: Фенікс, 2008. С. 66-73.

${ }_{5}^{5}$ Горох Н. Кадровый состав «Торгсина» (на примере Черниговской областной конторы) // Известия Гомельского государственного университета имени Ф. Скорины. 2014. Вып. 4 (85). С. 50-54; Горох М. Створення та діяльність Глухівської крамниці «Торгсин» (1933-1935 рр.) // Сіверщина в історії України: збірник наукових праць. 2012. С. 191-194; Горох М. «Торгсин» на Чернігівщині: спогади очевидців // Проблеми історії України: факти, судження, пошуки. 2008. Вип. 18. С. 176-181; Горох М. Іноземна валюта як джерело валютних надходжень Чернігівської обласної контори «Торгсин» // Український історичний збірник. 2011. Вип. 14. С. 131-137.

${ }^{6}$ Мельничук О. «Селяни і «Торгзін»: система заготівель побутового золота в УСРР (1932-1936 рр.) // Український селянин. 2010. Вип. 12. С. 281-283; Мельничук О. «Київська обласна контора «Торгсину» (1931-1936рр.): становлення та функціонування»: автореф. дис... канд. іст. наук : 07.00.01. Київ, 2015. 18 с.

${ }^{7}$ Міщук Я. Роль і діяльність системи «Торгзінів» Вінниччини на початку 1930-х рр. // Наукові записки Вінницького держ. педагогічного ун-ту ім. Михайла Коцюбинського. Серія: Історія. 2011. Вип. XIX. С. 70-74.

${ }^{8}$ Танасюк В.Л. Обмінно-валютні операції у системі Всесоюзного об'єднання «Торгзін» // Історія торгівлі, податків та мита. 2019. Вип. 1-2 (19-20). С. 157-166; Танасюк В.Л. Голодомор і «Торгзін»: джерела доходу торгівельної мережі 1932-1933 рр. // Український селянин. 2020. Вип. 1-2. С. $42-47$.

${ }^{9}$ Орешкин О.Ю. Организационно-правовые мероприятия по противодействию хищениям и злоупотреблениям в работе торговой сети Ивановской областной конторы Торгсин в 1933-1935 гг. // Вестник Владимирского юридического института. 2012. № 4. С. 162-165.

${ }^{10}$ Семенова Ф.Ю. Деятельность Вятского отделения Всесоюзного объединения «Торгсин» (1932-1936 гг.) // Вестник Вятского государственного гуманитарного университета. 2010. № 4 (1). С. 35-40.

${ }^{11}$ Осокина Е.А. Золото для индустриализации: «Торгсин»... С. 166. 
Маємо констатувати, що до появи «Торгзіну» питаннями портової торгівлі займався Радторгфлот (рос. «Совторгфлот» - советский торговый флот) - акціонерне товариство, створене 18 липня 1924 р. Ця судноплавна компанія об'єднувала транспортні кораблі, що належали в СРСР різним наркоматам і компаніям, у тому числі й змішаним, за участі іноземного капіталу. Заради справедливості варто зазначити, що організація постачання суден у радянських портах того часу була вкрай незадовільною, мала стихійний характер, якість товарів і послуг була досить низькою. Капітани закордонних суден намагалися забезпечувати товарами свої команди ще до заходу у радянські порти.

Фактично становлення «Торгзіну» в СРСР розпочалося з шипчандлерств - портової торгівлі з іноземними моряками й екіпажами радянських суден закордонного плавання міст Архангельська, Владивостока, Новоросійська, Одеси, Херсона, Миколаєва, Поті, Феодосії, Таганрогу. Створення портових «Торгзінів» стало частиною загального процесу централізації та мобілізації валюти для потреб індустріалізації. Особливого значення у цьому питанні набували порти Української СРР, оскільки вони, завдяки можливостям постійної навігації та виходу до теплих морів і океанів, зав'язували на собі значну кількість торгівельних напрямів і суден, що в них обслуговувалися, а також тримали першість з морського торгового обороту СРСР. Шипчандлерство стало важливим і дієвим кроком 3 акумуляції державою валюти та пропаганди радянського способу життя серед іноземців ${ }^{12}$.

Діяльність радянських шипчандлерств була далекою від ідеальної. Значна кількість портових «Торгзінів» ще за царату стали шипчандлерствами приватних фірм. Вони принесли з собою у «Торгзін» «пережитки капіталізму»: корупцію, соціальну сегрегацію, споювання моряків, залучення повій для обслуговування іноземців тощо. До цього додалася ще радянська специфіка - безгосподарність, дефіцит, низька якість продуктів і послуг, постійний контроль $з$ боку ОДПУ.

у лютому 1931 р. питання про постачання продуктами харчування та товарами експортної якості Інтернаціонального клубу моряків Одеського порту було практично вирішено. Однак Всесоюзне об'єднання «Торгзін» вимагало від керівництва порту обережного витрачання товарних фондів, розроблення порядку продажу цих товарів винятково іноземним морякам і недопускання продажу товарів з буфету стороннім особам. Уся виручка буфету повинна бути лише в іноземній валюті ${ }^{13} .3$ часом постало питання про можливість додаткового надходження валюти завдяки дозволу обслуговування іноземних громадян, що працювали в СРСР і моряків радянських суден закордонного плавання. Вони могли тут витрачати той резерв валюти, що у них залишався після повернення із закордонного плавання.

Для того, щоб наявну у членів екіпажів іноземних суден валюту команда не виносила на «чорний» ринок, була створена торгівельна мережа портових магазинів «Торгзіну». Суть роботи шипчандлера полягала у тому, щоб з прибуттям іноземного судна у радянський порт, прорекламувати можливості «Торгзіну» та домовитися з капітаном і командою про їх прикріплення до певного торгзінівського магазину, ресторану чи бару. Шипчандлер «Торгзіну» пропонував капітанові зробити замовлення на поповнення запасів продовольства, палива, будівельних матеріалів тощо. Для того, щоб зацікавити капіта-

\footnotetext{
${ }^{12}$ Ibid. C. 166.

${ }^{13}$ Державний архів Одеської області (далі - ДАОО). Ф. Р-1241. Оп. 1. Спр. 1. Арк. 7.
} 
на, шипчандлер платив йому гратифікаційні - кошти у вигляді премії. Реально ж це були відсотки від товарного замовлення, що не мали перевищувати 5\% вартості замовлення та виплачувалися як коштами, так і товаром «Торгзіну». Гратифікаційні були запозичені 3 практики закордонних портів і реально представляли собою хабар капітанові іноземного судна ${ }^{14}$.

Члени команди, в обмін на валюту, отримували бони «Торгзіну». На вимогу ОДПУ чи НКВС решта невитраченої валюти мала бути облікована капітаном, вилучена та зберігатися у спеціальному опломбованому сейфі. Ці заходи здійснювалися для того, щоб моряки не мали на руках готівки та не отоварювалися в інших магазинах чи на ринку. Асортимент портових торгзінівських магазинів був багатим на дорогі речі: марочний алкоголь, килими, хутра, тканини тощо. Однак у цих магазинах бракувало необхідних у повсякденні продуктів харчування та товарів першої необхідності. Тому морякам залишався один вихід - придбати вартісні дефіцитні товари у магазинах «Торгзіну», а потім обміняти або перепродати їх на місцевому ринку.

У діяльності Всесоюзного об'єднання «Торгзін» особлива увага приділялася розвитку торгових точок та сфери послуг портових міст, де була максимальна концентрація іноземних туристів, моряків іноземних суден і радянських кораблів закордонного плавання. Для цього, наприклад, в Одесі було створено акціонерне товариство «Готель» для прийому іноземців та організації закладів готельного типу в порту. В Одеській обласній конторі «Торгзін» у цій ініціативі побачили створення конкуруючої організації, яка послабить надходження іноземної валюти до їі торгових точок. Боротьба за іноземних клієнтів між акціонерним товариством «Готель» та Одеською обласною конторою стала масштабною і iї відголоски докотилися до вищих органів влади у Кремлі.

23 квітня 1931 р. була скликана нарада за участі голови ВЦВК СРСР М. Калініна, керівництва Наркомату зовнішньої торгівлі та Наркомату фінансів СРСР, акціонерних товариств «Інтурист», «Готель», Всесоюзного об’єднання «Торгзін» 15 . На цьому засіданні вдалося досягти консенсусу та домовитися про розмежування функцій між конкуруючими організаціями. Пріоритети у розгортанні портової торгівлі та можливості відкриття нових торгових точок надавалася Всесоюзному об'єднанню «Торгзін». Наркомзовнішторг СРСР і Наркомфін СРСР брали на себе відповідальність за розгортання роботи «Торгзіну». Акціонерне товариство «Готель» отримало право відкривати кіоски у своїх готелях, але постачання їх товарами залишили за «Торгзіном».

Валютний план Всесоюзного об'єднання «Торгзін» 1932 р. вимагав активізації діяльності шипчандлерств, збільшення об’ємів торгівлі на іноземну валюту. У липні 1931 p. їх валютний план становив 4,5 млн. крб. Однак Наркоматом зовнішньої торгівлі СРСР було переглянуто валютний план по всьому об'єднанню. На 1932 р. його було збільшено у 2,5 рази, а для шипчандлерств він зріс до 6,5 млн. крб. ${ }^{16}$ Виконати його стало б можливим лише за умови 100\% забезпечення суден у радянських портах через систему «Торгзін».

Можливості зростання туристичних потоків, чисельності іноземних суден, що фрахтуватимуться у радянських портах, породжували сподівання на стрімке зростання по-

\footnotetext{
${ }^{14}$ Осокина Е. «Советские дома терпимости»: рассказ о портовых «Торгсинах» 1930-х гг.... С. 52.

${ }^{15}$ ДАОО. Ф. Р-1241. Оп. 1. Спр. 2. Арк. 2.

${ }^{16}$ ДАОО. Ф. Р-1241. Оп. 1. Спр. 2. Арк. 243.
} 
ртової торгівлі і притік іноземної валюти та змушували керівництво шукати шляхи її активізації. У листі до обласних контор голова правління Всесоюзного об’єднання «Торгзін» М. Шкляр у серпні 1931 р. ставив перед шипчандлерствами завдання запобігати витрачанню іноземної валюти радянськими суднами і моряками за кордоном та максимально створювати умови для ефективної торгівлі з іноземцями у радянських портах ${ }^{17}$. Для цього правління Всесоюзного об'єднання закликало обласні контори «Торгзіну», які мали на своїй території порти, розширювати їх торгівельну мережу за рахунок відкриття нових універмагів, ларьків, кіосків, павільйонів. Першочерговими були поставлені завдання поліпшення якості обслуговування, розширення асортименту товарів, забезпечення торгових точок високоякісними експортними товарами за прийнятною ціною тощо. Ці й інші заходи мали сприяти зростанню у рази товарообігу в портових торгових точках.

Директори портових «Торгзінів» намагалися будь-якою ціною виконати доведений їм валютний план і використовували для цього усі можливі та неможливі способи. Часто за вітринами портових пунктів торгівлі приховувалися борделі, покликані максимально «викачати» кошти з іноземців. Мораль радянської людини формувалася правлячою комуністичною ідеологією і була покликана засуджувати негативні явища та пережитки «буржуазного минулого». Однак, як показала практика, мета виправдовувала засоби. Існування «злачних» місць у радянських портах цього періоду прикривалося державою через бездіяльність правоохоронних органів, а то, частіше всього, перебувала і під їх патронатом. Для «розкрутки» клієнтів тут пропонувалися послуги повій-комсомолок, які працювали у тандемі 3 торгзінівськими магазинами або Інтернаціональними клубами для моряків. Частину своїх заробітків повії віддавали своїм патронам з ОДПУ, а разом з ними й інформацію, яку вдавалося вивідати від іноземців. Відгуки моряків говорили самі за себе: «Вільність операцій «Торгзіну» створює враження першокласного публічного дому в капіталістичних країнах. Можливо, валюта і для п'ятирічки, але це справляє негативне враження на місцеве населення та формує негативний імідж країни, загалом, i «Торгзіну», зокрема» ${ }^{18}$.

На неподобства та негаразди в організації роботи портових «Торгзінів» відреагували у Москві. Лист голови правління Всесоюзного об'єднання «Торгзін» Артура Сташевського до керівництва Одеської обласної контори у кінці лютого 1933 р. засвідчив, що інформація про негаразди, які чинилися у припортових кафе та барах, дискредитувала саму організацію та вимагала негайно втрутитися у ситуацію. Не відмовляючись від можливості максимального вилучення валюти від клієнтів, управління Одеською обласною конторою закликали розібратися у ситуації та зберегти обличчя торгової установи ${ }^{19}$. У той же час і Всеукраїнська контора «Торгзіну» отримувала нарікання від правління Всесоюзного об’єднання на організацію роботи. Москва вимагала повного і безперебійного постачання продуктами харчування та промисловими товарами закордонних кораблів і радянських суден закордонного плавання. Недостатнє постачання суден у радянських портах загрожувало втратою клієнтів з такою бажаною на той час валютою у кишенях. Не дивлячись на те, що портові операції у загальному обороті Всеукраїнської контори «Торгзін» мали не

\footnotetext{
${ }^{17}$ ДАОО. Ф. Р-1241. Оп. 1. Спр. 2. Арк. 244.

${ }^{18}$ Центральний державний архів вищих органів влади і управління України (далі - ЦДАВО України). Ф. 4051. Оп. 1. Спр. 11. Арк. 22.

${ }^{19}$ ДАОО. Ф. Р-1241. Оп. 1. Спр. 18. Арк. 10.
} 
таку вже й значну вагу, однак валюта, що надходила через порти, вважалася ефективною валютою. Крім того, безперебійне постачання іноземних і радянських суден могло бути гарною рекламою усієї роботи «Торгзіну». Тому портовим магазинам надавалося право відбору необмеженої кількості товарів з міської торгівельної мережі та складів. Відповідальність за навіть мінімальне недопостачання суден покладалася персонально на керівництво Всеукраїнської контори «Торгзін» ${ }^{20}$.

Система шипчандлерства мала низку проблем, на які дуже часто скаржилися самі капітани іноземних суден. У переважній своїй більшості ці проблеми були пов'язані з високими цінами на товари, низькою їх якістю та несвоєчасною доставкою, а також спекуляцією бонами тощо. У шипчандлерствах бракувало співробітників зі знанням англійської мови. Інфраструктура портів потребувала модернізації. Зокрема, гострою була потреба в організації закладів гарячого харчування, припортових магазинів 3 високим рівнем обслуговування тощо. Для виправлення ситуації з негараздами у постачанні суден, керівництво Всеукраїнської контори «Торгзін» пропонувало обласним конторам вивчити питання з організації самозабезпечення: створення підсобних господарств, які б займалися вирощуванням високоякісної городини, розведенням птиці та худоби. Передбачалося, що вкладені кошти принесуть значний валютний зиск ${ }^{21}$.

Робота шипчандлерств Всесоюзного об'єднання «Торгзін» також пов'язувала свої проблеми з браком кваліфікованих кадрів, приміщень і належного постачання товарами. Керівництво портів часто демонструвало незацікавленість у співпраці 3 «Торгзіном», тому його склади та торгівельні точки часто знаходилися віддалено від портів, не завжди були належним чином обладнані та пристосовані до роботи.

У Кремлі також неабияк були зацікавлені в реалізації усіх напрямків роботи системи «Торгзін» $з$ акумуляції іноземної валюти. Виконанню цих завдань мала сприяти і належна організація роботи припортової торгівлі. Тому, у грудні 1932 р. Наркомат водного транспорту СРСР звертався з листом до Морагенств Радторгфлоту СРСР, начальників портів, партійних і радянських органів на місцях, покладаючи на них повну відповідальність за якість обслуговування закордонних і радянських суден закордонного плавання, зобов’язував сприяти шипчандлерствам «Торгзіну» в їх роботі ${ }^{22}$. Для покращенні організації роботи шипчандлерств безпосередньо на місцях правління Всесоюзного об’єднання «Торгзін» відрядило туди співробітників свого Портового сектора.

Результат не змусив себе довго чекати. Вже у серпні 1933 р. Всеукраїнська контора «Торгзін» звітувалася перед керівництвом сектору портової торгівлі Всесоюзного об’єднання «Торгзін» про посилення роботи шипчандлерства в українських портах. Новими об'єктами обслуговування стали пасажирські пароплави, які здійснювали рейси по близькосхідній лінії. Для прикладу, на одному з них (пароплаві «Чичерін») було встановлено торгзінівський кіоск 3 товарами, які користувалися попитом в іноземців: антикваріат, хутра, художні вироби, галантерейні та парфумерні товари, грамофони, платівки, біноклі тощо ${ }^{23}$. Ці товари передавалися Радторгфлоту для реалізації на комісійній основі.

\footnotetext{
${ }^{20}$ ЦДАВО України. Ф. 4051. Оп. 1. Спр. 11. Арк. 22.

${ }^{21}$ ЦДАВО України. Ф. 4051. Оп. 1. Спр. 11. Арк. 27.

${ }^{22}$ ЦДАВО України. Ф. 4051. Оп. 1. Спр. 11. Арк. 37.

${ }^{23}$ ЦДАВО України. Ф. 4051. Оп. 1. Спр. 11. Арк. 41.
} 
Значення Одеси, як одного з найбільших портів Союзу РСР і найбільшого порту України, було дуже вагомим. Одеський порт відвідувало по 350-400 іноземних суден на рік. Цей ключовий чинник, окрім іноземних туристів і транзитних іноземців, підвищував статус Одеського відділення «Торгзіну», робив його особливо важливим і відповідальним. Тому до Одеської обласної контори «Торгзін» були прикріплені власне Одеське, Херсонське та Миколаївське шипчандлерства.

6 серпня 1933 р. в Одесі відбулася нарада за участі представника правління Всесоюзного об'єднання «Торзін», начальника сектору портової торгівлі, директорів шипчандлерств, їх заступників і старших шипчандлерів. Управляючий Одеської обласної контори А. Пальцев і начальник сектору портової торгівлі Всесоюзного об’єднання «Торгзін» підкреслювали, що портовий оборот товарів торгівельних точок Одеської обласної контори утримує перше місце по всьому СРСР. Для збереження позитивної динаміки товарообігу директорам шипчандлерств потрібно було тримати на контролі товарну номенклатуру та привести ії̈ у відповідність до попиту. Якраз мав місце попит на ті товари, яких саме бракувало - на питну воду, овочі, молочну продукцію, сушені фрукти, рис, сигарети, будівельні матеріали, ліс, нафту, гас тощо. Крім того, була потреба врегулювання питання торгово-фінансового плану та приведення його у відповідність до кількості суден, що обслуговувалися українськими портами. Різниця у цінах на товари у торгзінівських магазинах Чорноморських портів також, до певної міри, дискредитувала їх роботу ${ }^{24}$.

Моряки радянських суден закордонного плавання та їх сім'ї мали право отоварюватися у портових магазинах «Торгзіну» за гарантійними листами і довідками капітанів. Цими документами доводилася законність наявної валюти, яка залишалася у результаті отримання екіпажами суден заробітної плати, оскільки 35\% її якраз виплачувалося саме валютою. Щоб ця валюта залишалася у СРСР, партійні та профспілкові органи проводили відповідну роботу з капітанами та командою суден з тим, щоб вони отоварювалися у портових торгзінівських магазинах за пільговими для них цінами. Така політика мала свій результат - близько 85\% зарплати моряків залишалося у «Торгзіні» ${ }^{25}$. Однак проблема своєчасного постачання портових магазинів системи «Торгзін» товарами експортної якості спонукала як радянських моряків, так і членів екіпажів іноземних суден витрачати чималі суми валюти й за кордоном.

Ключовим питанням було виконання плану шипчандлерствами Одеської обласної контори у III та IV кварталах 1933 р. У першому півріччі 1933 р. план по Одеському порту був виконаний на 97,6\%, з яких 102,1\% дало саме Одеське шипчандлерство, 82,2\% - Миколаївське, 70,2\% - Херсонське. Правлінням Всесоюзного об'єднання «Торгзін» пропонувалося при Одеській обласній конторі призначити відповідального за портову торгівлю, який би опікувався своєчасним постачанням усіма необхідними за заявками шипчандлерств товарами. Постала також необхідність створити спеціальний відділ будівельних матеріалів, який міг би зняти проблему недостатнього постачання суден ${ }^{26}$. Додатковим надходженням валюти могла стати організація в портах поточного ремонту суден, а також створення буфетів з асортиментом високоякісних товарів і забезпечення обслугову-

\footnotetext{
${ }^{24}$ ЦДАВО України. Ф. 4051. Оп. 1. Спр. 11. Арк. 58.

${ }^{25}$ ДАОО. Ф. Р-1241. Оп. 1. Спр. 2. Арк. 276.

${ }^{26}$ ЦДАВО України. Ф. 4051. Оп. 1. Спр. 11. Арк. 61.
} 
вання при інтерклубах тощо. Шипчандлерствам бракувало катерів, які б могли вільно доставляти корабельну команду на берег, а продукти і товари на судна. Проблемою була i відсутність автомобілів, якими можна було б перевозити команду судна до віддалених від портів торгівельних точок «Торгзіну».

У радянській державі, яка мала монополію на всі сфери життя, реклама не стала провідним чинником успішного розвитку торгівлі. Відсутність торгзінівської реклами в портах не давала можливості членам команди суден мати інформацію про існування портових магазинів та асортимент їх товарів. Відсутність складських приміщень створювала проблеми з розміщенням, збереженням і формуванням запасів товарів. Директори портових шипчандлерств, зі свого боку, вбачали наявність проблем у своїй роботі в недостатній увазі з боку обласної контори щодо діяльності самих портів, які б мали турбуватися про постачання їх магазинів необхідними товарами, рекламувати їі роботу, сприяти бункеруванню суден тощо. Низький рівень організації роботи радянських портів лякав капітанів іноземних суден і змушувала їх турбуватися про забезпечення кораблів у портах інших країн.

Належним чином організовані ці й інші заходи обласних контор щодо розвитку портів дали б можливість їм збільшити товарообіг та отримати заплановану валюту. Аналіз архівних даних дає можливість ствердитися у цій думці. Зокрема, якщо взяти матеріали Одеського порту в останньому кварталі 1932 р., то можна побачити, що у жовтні тут фрахтувалися 8 радянських суден і 12 іноземних, у листопаді - 7 радянських суден і 22 іноземних, у грудні, відповідно, 20 радянських і 26 іноземних суден. Їх тоннаж і чисельність екіпажу в середньому на одне судно складали: радянські - 4 тис. т і 45 осіб, іноземних - 7 тис. т і 35 осіб. Період стоянки в портах становив у середньому 15 діб ${ }^{27}$. Грамотне використання цього чинника та належна організація роботи портових шипчандлерств дали б позитивний результат в очікуваних валютних надходженнях.

Штат Одеського шипчандлерства налічував 32 особи, в числі яких були 3 шипчандлери, 14 продавців магазинів, 2 працівники буфету, 5 працівників бухгалтерії та 1 касир, 3 прибиральниці, 2 різноробочих і 2 працівники на катері. У жовтні 1932 р. послугами Одеського шипчандлерства скористалися 9 закордонних і 10 радянських суден. Отримана виручка склала: по іноземних кораблях - 8595 крб., по радянських - 10905 крб. і 17 тис. крб. припало на витрати сім'ями радянських моряків. Оскільки план товарообігу в жовтні 1932 р. мав скласти 42 тис. крб., то таким чином план був виконаний лише на 87\%. У листопаді 1932 р. в Одеському порту вже обслуговувалося 14 закордонних і 7 суден Радторгфлоту. Оборот шпичландерства зріс до 44531 крб., що становило 62,7\% від планового завдання ${ }^{28}$.

Миколаївське шипчандлерство обслуговувалося штатом у 12 осіб (3 шипчандлери, 1 завмаг, 1 помічник завмагу, 1 касир, 3 продавці, 1 учень, 1 робітник, 1 прибиральниця). У жовтні-листопаді 1932 р. тут обслуговувалися 30 суден. Виручка від їх обслуговування склала 24668 крб.

Якщо проналізувати товарообіг Одеського та Миколаївського шипчандлерств, то, у першу чергу, в очі кидається різниця у виручці від суден. Таку ситуацію можна було пояснити шестикілометровою віддаленістю Миколаївського шипчандлерства від портової

${ }^{27}$ ЦДАВО України. Ф. 4051. Оп. 1. Спр. 11. Арк. 77.

${ }^{28}$ ДАОО. Ф. Р-1241. Оп. 1. Спр. 18. Арк. 12-14. 
території. Тому екіпаж іноземного судна успішно тратив валюту в місцевому барі, що і вплинуло безпосередньо на недовиконання плану Миколаївським шипчандлерством.

Херсонське шипчандлерство обслуговував штат чисельністю у 6 осіб: шипчандлер, завмаг, продавець, 2 працівники буфету, прибиральниця. За жовтень-листопад 1932 р. тут обслуговувалися 22 судна на суму 7170 крб. Специфіка роботи цього шипчандлерства полягала у тому, що в Херсонському порту обслуговувалися, у переважній більшості, малі грецькі судна-лісовози, капітанами яких часто були самі власники суден. 3 метою економії на продуктах харчування, вони тримали на суднах живих баранів, свійську птицю тощо і таким чином уникали витрат у торгзінівських магазинах.

Проблема низької рентабельності південних портів того часу полягала і в іншому. Великі океанічні судна, які завантажувалися зерном, внаслідок мілководдя та засміченості українських портів, у Херсоні брали лише 60-70\% тоннажу, решту довантажували в інших портах. Як правило, закупівля продуктів харчування здійснювалася у кінцевому, перед тривалим плаванням, пункті. Тому завдання шипчандлерів українських портів полягали в тому, щоб відразу, з прибуттям судна до порту, зустрітися з капітаном і зав'язати 3 ним ділові стосунки, узгодити питання забезпечення команди продуктами харчування, відкриття для них кредиту в місцевому банку тощо. Шипчандлери забезпечували судна не лише продовольчими та промисловими товарами для команди, а й лісом, цементом, виробами з металу.

У своїй повсякденній роботі їм доводилося стикатися 3 комплексом проблем. У першу чергу, проблема шипчандлерств українських портів була в недостатньому забезпеченні портових складів овочами, свіжою рибою, ікрою, копченостями. Для забезпечення суден, шипчандлерам доводилося купувати їх у місцевих магазинах або вимінювати на ринку. Частими були нарікання щипландерств на недостатню увагу до них з боку Одеської обласної контори. Гостро стояла проблема наявності спеціально обладнаних приміщень, спецодягу для співробітників. Моряки ж, у свою чергу, скаржилися на високі ціни на хутряні й інші промислові товари. Проблем додалося ще й із запровадженням нової системи розрахунку: замість бонів Радторгфлоту вводилися забірні книжки «Торгзіну».

Узяти на себе вирішення проблемних питань мала нарада за участі представників обласної контори «Торгзін», Морагенства та Держбанку, що відбулася 8 квітня 1933 р. при Маріупольській міській Контрольній комісії Робітничо-селянської інспекції. 3 питання обслуговування іноземних суден було прийнято рішення торгівлю товарами здійснювати в наступний спосіб. Морагенство Радторгфлоту СРСР разом зі списками на видачу товарів капітанам і на видачу забірних книжок морякам радянських торгівельних суден, зобов’язувалося перерахувати на рахунок «Торгзіну» повну суму коштів.

Для отримання товарів капітанами іноземних суден Морагенство надало їм загальний гарантійний лист «Торгзіну» про те, що воно брало на себе відповідальність за всю суму, яку мали отримати капітани іноземних суден. Для безперебійного постачання іноземних суден Морагенство Радторгфлоту, відразу з прибуттям іноземного судна в порт, перераховувало кошти на попереднє покриття забору товарів капітаном на кожне судно 250 крб. Остаточний розрахунок здійснювався «Торгзіном» 3 Морагенством перед відбуттям судна з порту.

Для моряків іноземних суден замість бонів Радторгфлоту, Морагенство разом із за- 
явкою капітана іноземного судна передавало список членів екіпажу до «Торгзіну» на видачу забірних книжок. Це робилося одночасно з перерахуванням повної суми валюти за поданим списком. Моргагенство і «Торгзін» зобов'язали забезпечити процедуру видачі книжок, відпуск товарів, здійснення розрахунків тощо. За цієї нової системи розрахунків за товар, учасниками наради вимагалося ні в якому разі не допускати перебоїв в обслуговуванні суден товарами «Торгзіну». Вважалося, що раціональним було б організувати процес виготовлення та видачі книжок безпосередньо при Морагенствах. Для більш чіткої роботи у частині безперебійного відпуску «Торгзіном» товарів і своєчасного покриття Морагенством вартості цих товарів, потрібно було відкрити при Держбанкові спеціальний рахунок для цих операцій. Для цього мали просити правління «Торгзіну» і правління Радторгфлоту про відкриття Маріупольському порту спеціального рахунку для здійснення розрахунків 3 портової торгівлі ${ }^{29}$

Для своєчасного та належного обслуговування іноземних і радянських кораблів закордонного плавання у січні 1935 р. було прийнято «Положення про Спецконтору з портової торгівлі Всесоюзного об'єднання «Торгзін». Спецконтора підпорядковувалася голові правління Всесоюзного об’єднання «Торгзін», створювалася на основі повного господарського розрахунку, мала свій штат ${ }^{30}$. До завдань новоствореного підрозділу віднесли організацію, здійснення керівництва та планування портової торгівлі. Ї̈̈ співробітники вивчали ціни на товари у закордонних портах і запити членів екіпажів іноземних суден, розробляли прейскуранти для радянської портової торгівлі, рекламували товари тощо.

Результати діяльності Одеської обласної контори «Торгзін» упродовж усього часу її існування у переважній своїй більшості залежали від шипчандлерських операцій. Так, оборот портових торгівельних відділень продовжував зростати й у першому півріччі 1935 р. склав 361,2 тис. крб., а питома вага цих операцій стосовно усього обороту контори становила 30\%. Основне місце у цьому обороті займали операції з обслуговування сімей радянських моряків. Їх питома вага у товарообігу складала 47,7\%. Друге місце займали операції 3 постачання радянських суден закордонного плавання, питома вага яких складала 30,9\%. На третьому місця були операції з іноземними суднами 3 питомою вагою у 21,4\% ${ }^{31}$.

Показники розділилися між портами наступним чином:

\begin{tabular}{|l|l|c|c|c|c|}
\hline No & Портове & \multicolumn{2}{|c|}{ Питома вага в обслуговуванні у \% } & Усього \\
3/п & відділення & $\begin{array}{c}\text { сімей радянсь- } \\
\text { ких моряків }\end{array}$ & $\begin{array}{c}\text { радянських } \\
\text { суден }\end{array}$ & $\begin{array}{c}\text { іноземних } \\
\text { суден }\end{array}$ & \\
\hline 1. & Одеса & 54,6 & 31,3 & 14,1 & 100 \\
\hline 2. & Миколаїв & 13,6 & 33,8 & 52,6 & 100 \\
\hline 3. & Херсон & 39,8 & 8,9 & 51,3 & 100 \\
\hline
\end{tabular}

Виходячи з суми реалізації по кожному із портових відділень, їх питома вага виразилася у наступних цифрах: Одеса - 81,1\%, Миколаїв - 15,5\%, Херсон - 3,4\%32.

\footnotetext{
${ }^{29}$ ЦДАВО України. Ф. 4051. Оп. 1. Спр. 11. Арк. 117.

${ }^{30}$ ЦДАВО України. Ф. 4051. Оп. 1. Спр. 135. Арк. 94.

${ }^{31}$ ДАОО. Ф. Р-1241. Оп. 1. Спр. 28. Арк. 18.

32 ДАОО. Ф. Р-1241. Оп. 1. Спр. 29. Арк. 18.
} 
Отже, організація діяльності системи Всесоюзного об'єднання «Торгзін» була різнобічною та переслідувала одну мету - поповнювати золотовалютні резерви радянської держави для реалізації програми прискореної індустріалізації. Портовий директорат при В0 «Торгзін» і шипчандлерства були покликані перетворити портову торгівлю у канал стабільних надходжень валюти до державного бюджету. Важливого значення в організації цієї роботи надавали українським портам. Загалом, валютні доходи від портового господарства були незначними, однак, шипчандлерство, краще ніж інші операції у системі «Торгзін», розкрило його суть.

Ефективній організації радянської портової торгівлі заважали завищені ціни у порівнянні 3 найближчими закордонними портами. Програючи своїм закордонним конкурентам, «Торгзін» намагався зробити отоварювання у радянських портах для іноземних суден примусовим. Однак, сподівання на значний приплив валюти від шипчандлерських операції не виправдалися. Панування безгосподарності, зловживань, обмеженого та неякісного асортименту товарів, завищених цін і перебоїв з постачанням змушували капітанів закордонних суден знаходили способи відмовлятися від радянських портових послуг. Тому торгзінівська портова торгівля змогла протриматися, в основному, за рахунок обслуговування радянських суден закордонного плавання та постачання сімей моряків.

\title{
Vladylena Sokyrska
}

\section{«Currency for the Five Year Plan»: \\ Shipchandlerism in the system of the All-Union Association «Torgzin» of the first half of the 1930's}

\begin{abstract}
The article examines the organization of Torgzin's port trade in the first half of the 1930s. The activities of the system of the All-Union Union «Torgzin» were diverse, the key task was to replenish the gold and foreign exchange reserves of the Soviet state to implement the program of accelerated industrialization. It is proved that the creation of port trade became a part of the general process of mobilization and centralization of foreign currency for the needs of industrialization.

Torgzin was supposed to turn port trade into a channel for stable currency inflows into the state budget. It was established that the Soviet port trade was not properly organized. State regulation of trade, bureaucracy in decision-making hampered the initiative and did not allow to organize high-quality and uninterrupted supply of foreign ships and Soviet ships sailing abroad, to offer high-quality European service for crew members and passengers.

However, the directors of the port «Torgzin» tried at all costs to fulfill the currency plan proved to them and used all possible and impossible methods. It was found that although the foreign exchange earnings from the port economy were insignificant, shipchandling, better than other operations in the Torgzin system, revealed its essence.
\end{abstract}

Keywords: USSR, Ukrainian SSR, Torgzin, port trade, foreign vessels, currency 